\title{
Mass strandings of seven toothed and baleen whale species in Northern Norway in March 2020 call for further investigation
}

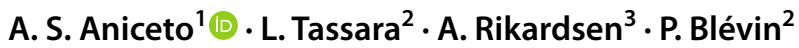

Received: 29 May 2020 / Revised: 5 March 2021 / Accepted: 11 March 2021 / Published online: 6 May 2021

(c) The Author(s) 2021, corrected publication 2021

\begin{abstract}
Monitoring whale strandings are a key aspect of ecosystem management as stranded animals can provide indications on ecosystem health, pollution and adverse effects due to anthropogenic activities. Most mass mortality events are reported for toothed whales and rarely involve baleen whales. In the course of one month in spring 2020, 17 whales belonging to seven different species, stranded on the shores of Northern Norway, above the Arctic circle. This multi-species event included humpback (Megaptera novaeangliae), fin (Balaenoptera physalus) and sperm whales (Physeter macrocephalus), that were accompanied by northern bottlenose whales (Hyperoodon ampullatus), a white-beaked dolphin (Lagenorhynchus albirostris), a long-finned pilot whale (Globicephala melas) and a harbour porpoise (Phocoena phocoena). We discuss some potential causes of death based on the previous literature and available information for the area, highlighting the need for further investigation on cetacean strandings at high latitudes. Ultimately, the reasons for the stranding could only be identified by a thorough examination of all the animals, which was unfortunately not conducted. As the threats to polar ecosystems and access to local shores are likely to increase, reports of cetacean mortality are also expected to surge, particularly in high latitude regions where climate variations and anthropogenic activities are increasing. This study makes recommendations for future steps and considerations for monitoring networks and standardized sampling methods for future marine mammal stranding events. Finally, we suggest that national and international efforts based on the collaborative relationships are implemented, considering the multiple facets of animal ecology and health as an achievable step in the near future.
\end{abstract}

Keywords Whale conservation $\cdot$ Mass strandings $\cdot$ Norwegian Arctic $\cdot$ Monitoring $\cdot$ Network

\section{Introduction}

Whale strandings are common globally, although to date there are still many challenges in identifying their cause. Large mass mortality events (MMEs), in particular, tend to involve toothed whales and are considered rare in baleen whales due to their less gregarious behaviour (Perrin et al. 2009). MMEs of baleen whales have often extended over several months and large areas, involving mostly coastal whales. Multi-species strandings are even more rare and

A. S. Aniceto

ana.s.aniceto@uit.no

1 Department of Fisheries and Bioeconomics, Arctic University of Norway, Troms $\varnothing$, Norway

2 Akvaplan Niva AS, Fram Centre, NO-9296 Tromsø, Norway

3 Department of Arctic Biology, Arctic University of Norway, Troms $\emptyset$, Norway indicates that some complex event may have happened that disrupted this species' habitat.

In March 2020, seventeen large whales (four humpback Megaptera novaeangliae, one fin whale Balaenoptera physalus, one unidentified, and six sperm whales Physeter macrocephalus) stranded on the beaches of Northern Norway (Fig. 1). The event took place over the course of 29 days and was accompanied by additional strandings of two northern bottlenose whales (Hyperoodon ampullatus), a white beaked dolphin (Lagenorhynchus albirostris), a long-finned pilot whale (Globicephala melas) and a harbour porpoise (Phocoena phocoena) (Bjørge et al. 2020; Johansen 2020a).

The location of the strandings, the Lofoten-Vesterålen archipelago, is known for its marine biodiversity richness, and sustains an important male sperm whale foraging ground at the continental shelf edge (Madsen et al. 2002). Humpback whales are often sighted during the winter months, although sporadic sightings have also been reported throughout the year (Jourdain and Vongraven 2017; Ramm 2020; 


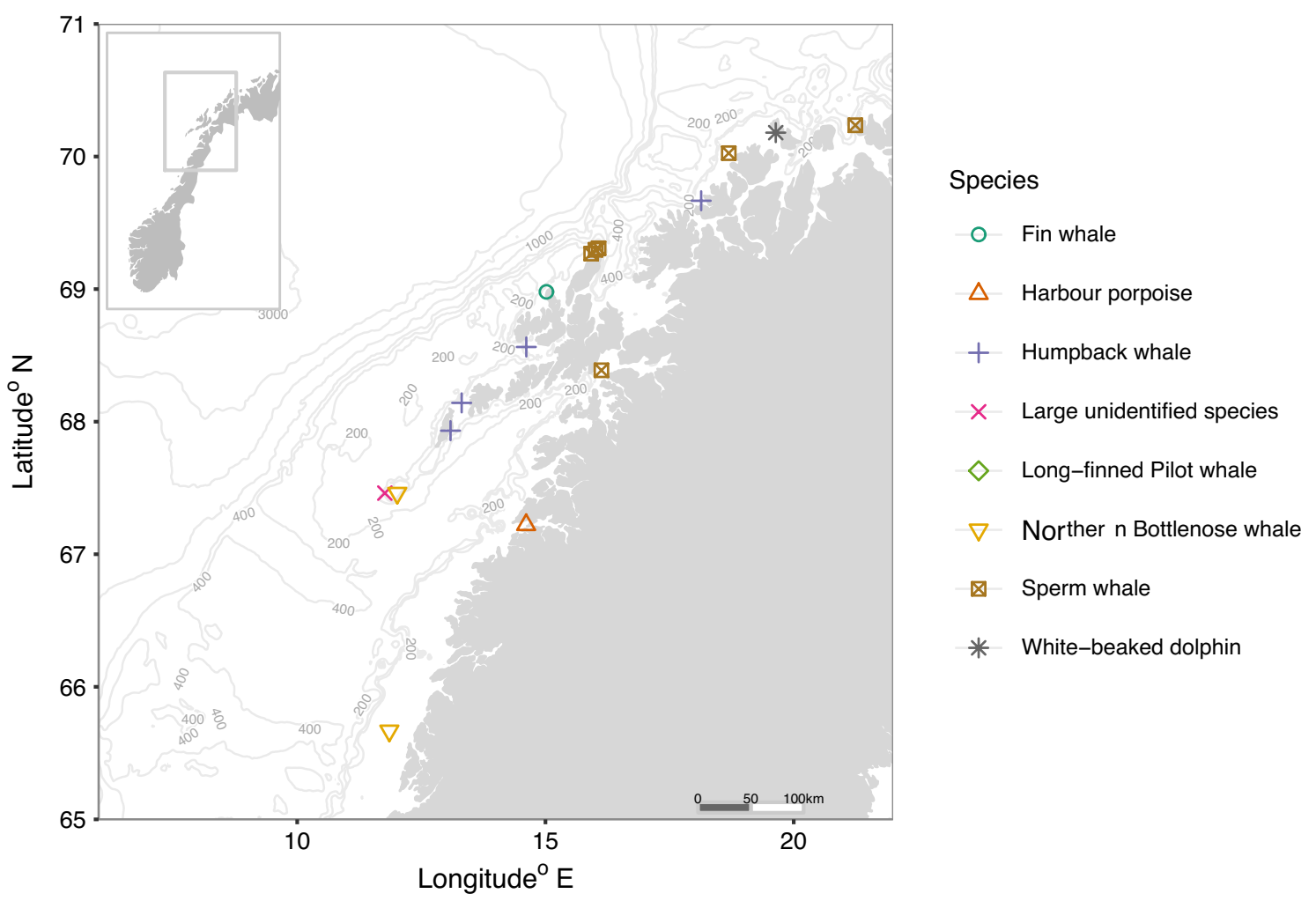

Fig. 1 Map with the sites where the majority of stranded whales were found (based on Bjørge et al. 2020). Note: only one reported sighting was located in southern Norway

Aniceto et al. 2020). Bottlenose whales and fin whales are assumed uncommon in the region, although fin whale vocalizations and visual observations have been reported during winter and summer, respectively (Øygard 2018; Leonard and Øien 2020). Minke whales (Balaenoptera acutorostrata) and killer whales (Orcinus orca) are also often sighted during that period of the year though none were found. Killer whale high mobility in the Norwegian Sea (Dietz et al. 2020) following the Norwegian Spring Spawning herring (Clupea harengus) migration (Similä et al. 1996; Kuningas et al. 2014; Vogel et al. 2021) or Atlantic Mackerel (Scomber scombrus) (Nøttestad et al. 2014) could have spared these animals from a similar fate.

Strandings of large whales in Norway are not uncommon. The seasonal presence of large densities of humpback whales during the winter (Broms et al. 2015; Jourdain and Vongraven 2017), and residency of sperm whales (Rødland and Bjørge 2015) in the region, together with an increase in the awareness of their presence in small localities, raise the chances of strandings being detected and reported. However, the last recorded mass-stranding of whales in this region occurred in the late 80 s (Christensen 1990) where the author concluded that the animals had not died in Norwegian waters, but rather drifted from other locations around the North Atlantic. Similarly, the specimens in 2020 also appeared to be already deceased during the event and presented different degrees of decomposition (see Dahlen and Christoph Noever 2020). Yet, both the humpback and sperm whales were observed to be relatively fresh (no signs of external decomposition or breakage of the outer tissue) and appear to have originated from the Norwegian Sea, West of the Lofoten islands (Johansen 2020a). The overarching goal of this review is to increase awareness of this events globally and prioritize management and conservation actions.

\section{Materials and methods}

We review a mass stranding event occurring in Northern Norway in 2020 (as reported by Bjørge et al. 2020), highlighting potential causes and respective counterarguments for the deaths of baleen and odontocete species based on the previously reported global events. We briefly summarize evidence from historical studies on different cetacean species and identify features and common causes for stranding.

\section{Results and discussion}

As whales are considered sentinels of the marine ecosystem, they are globally exposed to multiple stressors. Ship strikes, by-catch, anthropogenic noise, chemical pollution 
and habitat loss (Clapham et al. 1999; Bossart 2011) are some of the most predominant causes for mortality. Moreover, since ocean conditions directly influence quality and availability of prey, the effects of climate change are a raising concern (Simmonds and Isaac 2007; Häussermann et al. 2017). Threats to marine ecosystems and human access to local shores are likely to increase, which may lead to a surge in reports of strandings. Whale strandings can not only provide information on the individual cause of death, but also information on animal biology, oceanographic drifting, and changes in the marine environment. Although the cause of mortality of cetaceans cannot often be conclusively identified (Gulland et al. 2005; Coughran et al. 2014), some baleen whales and multi-species mortality events have been linked to bio-oceanographic conditions, such as harmful algal blooms (HABs) (Fire et al. 2010; Lefebvre et al. 2016; Wilson et al. 2016; Häussermann et al. 2017). In this assemblage, all individuals could not be tested for viruses or bacteria, due to the quick intervention of the coast guard for removal of the carcasses and the delayed response by sampling teams. Although there was no clear/visible evidence of pathological modifications that could be attributed to such a cause (see Dahlen and Christoph Noever 2020), it is not possible to discard this hypothesis without further investigation. Satellite imagery from the time was not possible to obtain due to strong cloud coverage (Johansen 2020b). Furthermore, offshore winds were very predominant (Met. no 2020) and can also allude to a cause of the mass mortality found in Norway. Strong and persistent wind and storm events may cause strandings through disorientation, confused navigation due to bathymetric conditions, distraction from feeding activities, or additional energetic costs (Vanselow and Ricklefs 2005; Evans et al. 2005; Pierce et al. 2007). The unusual strong winds towards land could indeed have brought to shore animals that died of different causes and at different periods of time, raising questions about the number of dead animals unaccounted for in Norwegian waters. Also, winds can boost marine productivity and may result in a net movement of cetaceans following their prey towards the same location; thereby, increasing the number of whales available to strand in the region (Evans et al. 2005). However, a 25-year study on humpback whale strandings in Australia showed that most of the stranded whales were calves and juveniles and suggests that mortality due to weather events seems to be less likely than mortality due to effects of human activity or water quality (Meynecke and Meager 2016). The only potentially lethal sound-related mechanism for a baleen whale are very intense noises associated with blasting in close proximity (Ketten 1995). This could injure the animal and cause hemorrhage or provoke panic, displacement, favor entrapment (Goldbogen et al. 2013) and even decompression sickness (Bernaldo De Quirós et al. 2019). Military activity in the region has been reported in national news (Skeie and Sørgård 2020), although there has been unclear information concerning any activities during that period of time. In addition, air-gun shooting for petroleum exploration did not occur in the region nor during that period of time (Oljedirektoratet 2020). The strongest argument against the hypothesis that intense noise is the cause of the stranding, is the lack of evidence as we could find only a single reported stranding of baleen and odontocete species at the same time due to military sonar (Balcomb III and Claridge 2001). The most likely answer to the question "why have the whales stranded?" would be through a thorough examination of all the carcasses, which was unfortunately not performed at the time.

In the case of the Northern Norwegian stranding events here discussed it was not possible to conclude a cause of death and the hypotheses mentioned above are for now only speculative. Yet, as we experience borealization of species and increased interactions with anthropogenic activities, we urge national and international authorities globally to intervene and assess the causes and implications of all stranding events. Although this study does not account for cumulative threats to marine mammals, we recognize that there is a multitude of combined natural and anthropogenic contributors to ecosystem alteration. Similarly, we recognize that there are several stranding events that occur naturally over time, although it is important to emphasize that the absence of strandings in a region does not implicate an absence of deaths due to external pressures (i.e., absence of evidence does not mean evidence of absence). The establishment of an integrative stranding network at a national level is, therefore essential for long-term assessments of change in marine ecosystems and governance initiatives. Such network is already underway, which signifies a great incentive to improve management and conservation efforts. However, quick response teams are still under multiple nonprofit organizations and the lack of integration of efforts is an issue that we advise being tackled sooner rather than later.

We therefore make the following recommendations: 1) Establish regular workshops and discussions amongst stakeholders (scientists and management institutions, such as the International Whaling Commission and the North Atlantic Marine Mammal Commission), in collaboration with maritime security agencies (Norwegian coast guard) to provide a better integration amongst institutions and allow results to be brought to the governance level; 2) Develop a unified reporting system that will allow for quick and thorough response for local teams with standardized sampling methods and metrics; 3) Create a single database for stranding events that allows for the national scientific community to work more collaboratively on improving the current knowledge of marine mammal wildlife. It is important to 
consider the need for a multidisciplinary approach, including toxicologists, oceanographers, acousticians and ecologists among others, to broaden the scope of the network, solve the causes of stranding, and cover the long Norwegian coastline. Finally, we recognize that complexity-focussed approaches to marine mammal research and conservation are poised to advance (Lewison et al. 2018), and suggest that national and international efforts based on the collaborative relationships are implemented, considering the multiple facets of animal ecology and health as an achievable step in the near future.

Acknowledgements We thank the groups "hvaler i nord", "Marine Animal Strandings Network of Norway" and the Norwegian Orca Survey for reporting the stranded animals and for providing a timeline for their occurrence. We also thank Eskild Johansen at Fiskeribladet for allowing a fruitful discussion amongst scientists and public on the possible causes of these strandings. Many thanks to Lisa Kettemer for discussing potential outcomes and future measures for integrating stakeholder efforts. A great thank you to Prof. Raul Primicerio for providing feedback on the "bigger picture" of the importance of strandings for ecosystem-based management and governance of national waters. Finally, we would like to thank the two reviewers (including Dr. Edda Magnusdottir) who have offered to comment on the manuscript and ensure peer-review quality.

Authors' contributions ASA, LT, and PB conceptualized and designed this review. ASA procured information on the stranded animals. ASA led the writing of the manuscript with input of LT, AR and PB. All authors approved the submitted version.

Funding Open access funding provided by UiT The Arctic University of Norway (incl University Hospital of North Norway). Funding for this work was provided by a postdoc scholarship from VISTA-a research programme in collaboration between the Norwegian Academy of Sciences and Letters and Equinor. No further funding was involved.

Availability of data and material All data and material used in this study are available upon request to the corresponding author.

\section{Declarations}

Conflict of interest The authors declare that the research was conducted in the absence of any commercial or financial relationships that could be construed as a potential conflict of interest. Furthermore, there were no non-financial conflicts in the development of this study.

Consent for publication All authors consent to the publication of this manuscript.

Open Access This article is licensed under a Creative Commons Attribution 4.0 International License, which permits use, sharing, adaptation, distribution and reproduction in any medium or format, as long as you give appropriate credit to the original author(s) and the source, provide a link to the Creative Commons licence, and indicate if changes were made. The images or other third party material in this article are included in the article's Creative Commons licence, unless indicated otherwise in a credit line to the material. If material is not included in the article's Creative Commons licence and your intended use is not permitted by statutory regulation or exceeds the permitted use, you will need to obtain permission directly from the copyright holder. To view a copy of this licence, visit http://creativecommons.org/licenses/by/4.0/.

\section{References}

Aniceto AS, Pedersen G, Primicerio R et al (2020) Arctic marine data collection using oceanic gliders: Providing ecological context to cetacean vocalizations. Front Mar Sci. https://doi.org/10.3389/ fmars. 2020.585754

Balcomb KC III, Claridge DE (2001) A mass stranding of cetaceans caused by naval sonar in the Bahamas. Bahamas J Sci 8:2-12

Bernaldo De Quirós Y, Fernandez A, Baird RW et al (2019) Advances in research on the impacts of anti-submarine sonar on beaked whales. Proc R Soc B Biol Sci. https://doi.org/10.1098/rspb.2018. 2533

Bjørge A, Ryeng K, Jourdain E, Wiig J (2020) A short note on unusual high frequency of cetacean strandings in Northern Norway , 28 th March - 2 nd May 2020. IWC report SC/68B/E/06

Bossart GD (2011) Marine mammals as sentinel species for oceans and human health. Vet Pathol. https://doi.org/10.1177/03009 85810388525

Broms F, Wezel F, López Suárez P, et al (2015) Recent research on the migratory destinations of humpback whales (Megaptera novaeangliae) from a mid-winter feeding stop-over area in Northern Norway. In: Wenzel FW (ed) Recent research on the migratory destinations of humpback whales (Megaptera novaeangliae) from a mid-winter feeding stop-over area in Northern Norway. European Cetacean Society Special Publication Series, 22 March 2015, St. Juliens, Malta

Christensen I (1990) A note on recent strandings of sperm whales (Physeter macrocephalus) and other cetaceans in Norwegian waters. Rep Int Whal Comm 40:513-515

Clapham PJ, Young SB, Brownell RL (1999) Baleen whales: conservation issues and the status of the most endangered populations. Mamm Rev. https://doi.org/10.1046/j.1365-2907.1999.00035.x

Coughran DK, Gales NJ, Smith HC (2014) A note on the spike in recorded mortality of humpback whales (Megaptera novaeangliae) in Western Australia. J Cetacean Res Manag 13:105-108

Dahlen PV, Noever C (2020) MASNN - Marine Animal Stranding Network Norway, forum. https://www.facebook.com/groups/40541 7266521590. Acessed 20 March 2020

Dietz R, Rikardsen AH, Biuw M et al (2020) Migratory and diurnal activity of North Atlantic killer whales (Orcinus orca) off northern Norway. J Exp Mar Bio Ecol 533:151456. https://doi.org/10. 1016/j.jembe.2020.151456

Evans K, Thresher R, Warneke R et al (2005) Periodic variability in cetacean strandings: links to large-scale climate events. Biol Lett 1:147-150. https://doi.org/10.1098/rsbl.2005.0313

Fire SE, Wang Z, Berman M et al (2010) Trophic transfer of the harmful algal toxin domoic acid as a cause of death in a minke whale (Balaenoptera acutorostrata) stranding in southern California. Aquat Mamm. https://doi.org/10.1578/AM.36.4.2010.342

Goldbogen JA, Southall BL, DeRuiter SL et al (2013) Blue whales respond to simulated mid-frequency military sonar. Proc R Soc B Biol Sci. https://doi.org/10.1098/rspb.2013.0657

Gulland F, Pérez-Cortés H, Urbán JR, et al (2005) Eastern North Pacific gray whale (Eschrichtius robustus) unusual mortality event, 1999_ 2000. US Dep Commer NOAA Tech Memo NMFS-AFSC-150

Häussermann V, Gutstein CS, Beddington M et al (2017) Largest baleen whale mass mortality during strong El Niño event is likely related to harmful toxic algal bloom. PeerJ 5:e3123. https://doi. org/10.7717/peerj.3123

Johansen E (2020a) Avansert simulering viser at de døde hvalene trolig kom fra havet vest for Lofoten. In: Fiskeribladet. https://www.fiske ribladet.no/nyheter/avansert-simulering-viser-at-de-dode-hvale ne-trolig-kom-fra-havet-vest-for-lofoten/2-1-800107. Accessed 30 April 2020 
Johansen E (2020b) Hvalforsker mistenker at dødsalger har tatt livet av hvalene. In: Fiskeribladet. https://www.fiskeribladet.no/nyhet er/hvalforsker-mistenker-at-dodsalger-har-tatt-livet-av-hvalene/21-802112. Accessed 7 May 2020

Jourdain E, Vongraven D (2017) Humpback whale (Megaptera novaeangliae) and killer whale (Orcinus orca) feeding aggregations for foraging on herring (Clupea harengus) in Northern Norway. Mamm Biol 86:27-32. https://doi.org/10.1016/j.mambio.2017. 03.006

Ketten DR (1995) Estimates of blast injury and acoustic trauma zones for marine mammals from underwater explosions. In: Kastelein RA, Thomas JANPE (eds) Sensory Systems of Acquatic Mammals. De Spil Publishers, Woerden, The Netherlands

Kuningas S, Similä T, Hammond PS (2014) Population size, survival and reproductive rates of northern Norwegian killer whales (Orcinus orca) in 1986-2003. J Mar Biol Assoc United Kingdom 94:1277-1291. https://doi.org/10.1017/S0025315413000933

Lefebvre KA, Quakenbush L, Frame E et al (2016) Prevalence of algal toxins in Alaskan marine mammals foraging in a changing arctic and subarctic environment. Harmful Algae. https://doi.org/10. 1016/j.hal.2016.01.007

Leonard D, Øien N (2020) Estimated abundances of cetacean species in the northeast atlantic from norwegian shipboard surveys conducted in 2014-2018. NAMMCO Sci Publ Doi 10(7557/3):4694

Lewison RL, Johnson AF, Verutes GM (2018) Embracing complexity and complexity-awareness in marine megafauna conservation and research. Front Mar Sci 5:207. https://doi.org/10.3389/fmars. 2018.00207

Madsen PT, Wahlberg M, Møhl B (2002) Male sperm whale (Physeter macrocephalus) acoustics in a high-latitude habitat: Implications for echolocation and communication. Behav Ecol Sociobiol 53:31-41. https://doi.org/10.1007/s00265-002-0548-1

Met.no (2020) Avsluttet farevarsel: Svært kraftige vindkast nord i Nordland. Meteorol. Inst. Accessed 30 April 2020

Meynecke J-O, Meager JJ (2016) Understanding Strandings: 25 years of Humpback Whale (Megaptera novaeangliae) Strandings in Queensland, Australia. J Coast Res 75:897-901. https://doi.org/ 10.2112/si75-180.1

Nøttestad L, Sivle L, Krafft B et al (2014) Prey selection of offshore killer whales Orcinus orca in the Northeast Atlantic in late summer: spatial associations with mackerel. Mar Ecol Prog Ser 499:275-283. https://doi.org/10.3354/meps 10638

Oljedirektoratet (2020) Overview of acquisitions on Norwegian Confinental Shelf. In: Overv. Surv. https://factpages.npd.no/en/survey/ tableview/all. Accessed 15 April 2020
Øygard SH (2018) Simulations of acoustic transmission loss of Fin whale calls reaching the LoVe Ocean Observatory. MSc dissertation, University of Bergen

Perrin WF, Wursig B, Thewissen JGM (2009) Encyclopedia of Marine Mammals. Elsevier Ltd

Pierce GJ, Santos MB, Smeenk C et al (2007) Historical trends in the incidence of strandings of sperm whales (Physeter macrocephalus) on North Sea coasts: An association with positive temperature anomalies. Fish Res 87:219-228. https://doi.org/10.1016/j.fishr es.2007.06.001

Ramm T (2020) Hungry during migration? Humpback whale movement from the Barents Sea to a feeding stopover in northern Norway revealed by photo-ID analysis. MSc dissertation, UiT The Arctic University of Norway

Rødland ES, Bjørge A (2015) Residency and abundance of sperm whales (Physeter macrocephalus) in the Bleik Canyon, Norway. Mar Biol Res 11:974-982. https://doi.org/10.1080/17451000. 2015.1031800

Similä T, Holst JC, Christensen I (1996) Occurrence and diet of killer whales in northern Norway: seasonal patterns relative to the distribution and abundance of Norwegian spring-spawning herring. Can J Fish Aquat Sci 53:769-779. https://doi.org/10.1139/f95-253

Simmonds MP, Isaac SJ (2007) The impacts of climate change on marine mammals: early signs of significant problems. Oryx 41:19-26. https://doi.org/10.1017/S0030605307001524

Skeie K, Sørgård KO (2020) Russisk skyteøvelse utenfor norskekysten for tredje gang på under ett år. NRK. https://www.nrk.no/nordl and/russisk-skyteovelse-utenfor-norskekysten-for-tredje-gang-paunder-ett-ar-1.14890421. Accessed 15 April 2020

Vanselow KH, Ricklefs K (2005) Are solar activity and sperm whale Physeter macrocephalus strandings around the North Sea related? J Sea Res 53:319-327. https://doi.org/10.1016/j.seares.2004.07. 006

Vogel EF, Biuw M, Blanchet MA, et al (2021) Killer whale movements on the Norwegian shelf are associated with herring density. Mar Ecol Prog Ser (in press):

Wilson C, Sastre AV, Hoffmeyer M et al (2016) Southern right whale ( Eubalaena australis ) calf mortality at Peninsula Valdés, Argentina: Are harmful algal blooms to blame? Mar Mammal Sci 32:423-451. https://doi.org/10.1111/mms.12263

Publisher's Note Springer Nature remains neutral with regard to jurisdictional claims in published maps and institutional affiliations. 